\title{
РЭЦЭНЗІІ
}

\section{Literatura Białorusinów polskich w kręgu nowych zainteresowań badawczych}

Helena Duć-Fajfer, Pomiędzy bukwa a litera. Wspótczesna literatura mniejszości białoruskiej, ukrainskiej $i$ temkowskiej w Polsce, Wydawnictwo Uniwersytetu Jagiellońskiego, Kraków 2012, 362 str.

Białoruskie Stowarzyszenie Literackie „Białowieża”, istniejące już od ponad półwieku (8 czerwca 2013 roku odznacza swój 55-letni jubileusz), może się poszczycić wieloma znakomitymi dziełami literackimi (poezja, proza, eseistyka, wspomnienia, dzienniki), które w swoim czasie zostały zauważone przez krytykę krajową i zagraniczną, wysoko ocenione i które, jak się wydaje, na trwałe weszły do ogólnej skarbnicy kultury białoruskiej, a także w jakimś stopniu i do historii literatury polskiej, zwłaszcza tej jej części, która zajmuje się literaturą pogranicza kulturowego, obrzeżami literatury.

Twórczość literacka Białorusinów polskich od samego początku ich działalności była pod baczną uwagą polskiej krytyki. Ale dopiero na początku lat dziewięćdziesiątych ubiegłego wieku po przekroczeniu przez pisarzy tego Stowarzyszenia pewnej masy krytycznej, pojawiają się pierwsze gruntowne opracowania naukowe, których przedmiotem analizy staje się właśnie literatura białoruska tworzona w Polsce.

Pierwszeństwo w tych badaniach literaturoznawczych należy się Teresie Zaniewskiej, polonistce, wówczas pracownikowi naukowemu Filii Uniwersytetu Warszawskiego w Białymstoku, dziś - profesorowi SGGW w Warszawie. W 1992 roku wydaje ona $\mathrm{w}$ Białymstoku, powstała z bliskich obserwacji i kontaktów z pisarzami, książkę pod tytułem „Podróż daremna. Szkice o poezji białoruskojęzycznej w Polsce". Rok później ukazuje się tamże jej bardzo interesujący tom wywiadów „A dusza jest na Wschodzie. Polsko-białoruskie związki literackie”, w którym jest sporo zaskakująco trafnych spostrzeżeń, uwag i konkluzji o „Białowieżanach”. Po czterech latach, w 1997 roku Teresa Zaniewska publikuje swoją trzecią książkę, tym razem rozprawę habilitacyjną zatytułowaną „Strażnicy pamięci. Poezja białoruska w Polsce po roku 1956".

Powyższe publikacje doświadczonej badaczki, bazujące na rozległym materiale egzemplifikacyjnym i gruntownej znajomości obszernej literatury krytycznej przedmiotu, są z wielu względów także dziś nie do przecenienia. Jedną z najważniejszych ich zalet jest zapewne to, że w tych pracach został sformułowany przez Teresę Zaniewską i wyraźnie odzwierciedlony polski punkt widzenia, z którego rozpatruje 
Autorka twórczość literacką „Białowieżan” jako organiczny składnik wielokulturowej i wielonarodowej Rzeczypospolitej Polski. Wobec wcześniej prezentowanego przez niektórych uczonych białoruskiego punktu widzenia (m.in. W. Hniłamiodow, A. Ramanczuk) oraz opcji angielskiej (A. McMillin wpisuje „Białowieżan” w kontekst „diaspory białoruskiej”), samym pisarzom Stowarzyszenia pogląd Teresy Zaniewskiej wydaje się być najbliższy. Jej prace zarysowały zatem określoną perspektywę badawczą dla innych literaturoznawców, zwłaszcza slawistów polskich, którzy podążą jej śladem. W 2004 roku w Lublinie, nakładem wydawnictwa KUL, pojawia się rozprawa doktorska Beaty Siwek pod tytułem „Ojczyzna duża i mała. Poeci Białoruskiego Stowarzyszenia Literackiego „Białowieża” wobec problematyki ojczyźnianej", a w 2012 w Białymstoku ukazuje się drukiem również praca doktorska Anny Sakowicz „Беларуская літаратура Польшчы. Стылістычна-жанравыя асаблівасці прозы "белавежцаў". W tym samym 2012 roku w wydawnictwie Uniwersytetu Jagiellońskiego w Krakowie zostaje ogłoszona książka Heleny Duć-Fajfer „Pomiędzy bukwą a literą. Współczesna literatura mniejszości białoruskiej, ukraińskiej i łemkowskiej w Polsce", pomyślana jako rozprawa habilitacyjna, w której literatura Białorusinów polskich jest oświetlona ze zgoła innego niż u Zaniewskiej punktu widzenia. Ponieważ jest to rzecz zachęcająca do dyskusji, warto chociażby z tego tytułu wypowiedzieć się o niej szerzej.

Na wstępie trzeba powiedzieć, że dorobek naukowy Heleny Duć-Fajfer jest dość swoisty. Po pierwsze dlatego, że obszarem problemowym jej zainteresowań badawczych jest, mówiąc skrótowo, wyłącznie sprawa łemkowska - łemkowska historia, kultura, życie religijne, etniczność, etnografia, język, piśmiennictwo, literatura, szkolnictwo. Wszystkie te aspekty życia Łemków rozpatrywane są w różnych kontekstach, wymiarach i zestawieniach. Nie ma wątpliwości, że na dzień dzisiejszy mamy do czynienia ze znakomitą znawczynia w tej dziedzinie, biegłą w tej specjalności, na co dobitnie wskazuje wydana w 2001 roku jej 400 stronicowa monografia pod tytułem „Literatura łemkowska w drugiej połowie XIX i na początku XX wieku", będąca w istocie rzeczy swoistą encyklopedią łemkowską, jedynym w Polsce kompetentnym źródłem wiedzy o tej społeczności. Jednakże ta cenna sama w sobie wąska specjalność może budzić i budzi pewien niepokój i niedosyt. Bowiem Autorka jest badaczem stojącym nie na zewnątrz przedmiotu swych dociekań, lecz w samym środku. Mało tego, jest bardzo aktywną, jak sama pisze, współuczestniczką i współkreatorką odrodzenia kulturowo-etnicznego Łemków w Polsce (s. 11). Z tego wszakże wynika, że jej ustalenia, opinie, charakterystyki, sądy, przekonania, poglądy, oceny, uogólnienia i konkluzje z natury rzeczy są wszędzie zabarwione mniejszą lub większą subiektywnością, niezależną zresztą od Autorki i być może nawet przez nią nie uświadamianą.

Po drugie, jej prace naukowe mają charakter wyraziście interdyscyplinarny, co w prostej linii wydaje się być wynikiem szerszych zainteresowań, popartych dodatkowymi studiami w zakresie historii sztuki oraz psychologii, które Duć-Fajfer zdążyła ukończyć między uzyskaniem stopnia magistra oraz stopnia doktora z literaturoznawstwa rosyjskiego $(1985,1997)$. Żarliwym zwolennikiem takiego sposobu uprawiania badań naukowych w polskiej slawistyce był świętej pamięci profesor Ryszard Łużny. W obu literaturoznawczych pracach dyplomowych jej promotorem był właśnie profesor Łużny i, jak widać, z dobrym skutkiem. Recenzowana 
książka jest kolejnym dowodem odejścia przez Autorkę od, powiedzmy, tradycyjnego czy też klasycznego zajmowania się literaturą i szukanie dla niej nowych podejść i rozwiązań na styku z nią różnych dyscyplin naukowych przez odwołanie się do prac kulturologicznych, socjologicznych, etnoznawczych, socjolingwistycznych, politologicznych, antropologicznych, filozoficznych. Jednak nadmierne korzystanie z ich zaplecza teoretycznego, z ich instrumentarium pojęciowego, wreszcie kluczy oraz dedukcyjnej metody myślenia musi nieuchronnie prowadzić do zmiany poetyki artykułu literaturoznawczego, jego kompozycji, a zwłaszcza stylistyki. W dużych fragmentach w rozprawie stylistyka staje się wyraziście polemiczna, interwencyjna, publicystyczna, poprzez którą przemawia radykalizm postawy, ujęć, interpretacji. Tak zapewne jest realizowany postulat rzeczywiście humanistyki zaangażowanej, tej i takiej, która, jak widać. jest bliska sercu Autorki. Duć-Fajfer sama zdaje się odczuwać potrzebę ustosunkowania się do tej innowacyjności, przeto w książce próbuje jakoś zaklasyfikować swój warsztat. Oto w Zakończeniu książki pisze: „sytuuję siebie w nurcie badań postzależnościowych jako nowej tendencji literaturoznawczej" (s. 316) i tamże, nieco dalej, mówi o swoim podejściu badawczym jako o „spojrzeniu antropologizującego literaturoznawcy”.

To piękne i chwalebne słowa. Sądzę jednak, że prościej byłoby wykorzystać starą i bardziej pojemną nazwę, jaką jest kulturoznawstwo lub socjologia literatury. Socjologia nie jest pojęciem pejoratywnym i socjologiczne metody w badaniach literackich stosuje się z powodzeniem, zwłaszcza na tych obszarach badawczych, którym jest poświęcona ta książka - nad społecznym uwarunkowaniem dzieła literackiego, próbując odpowiedzieć na pytanie, w jaki sposób sytuacja społeczna pisarza określa jego poczynania literackie, w szczególności zaś, jak sytuacja społeczna odzwierciedla się w świecie przedstawionym i zawartości ideowej jego dzieł. Mówię o tym, ponieważ Autorka sama lokuje siebie w tej przestrzeni, gdy mówi we Wstępie o celach swojej rozprawy. Pisze: „Książka ta ma na celu (...) ujawnić i zilustrować poprzez cytaty (...) przede wszystkim wewnętrzną mobilizację podporządkowanych wspólnot wokół na różne sposoby wzmacnianych wartości" (s. 10). Dalej: „W pisaniu książki przyświecały mi pewne założenia i postulaty społeczne współczesności, które istotnie generuja postawy zaangażowane, wpływają też w wysokim stopniu na (...) dokonywane interpretacje zdarzeń, zjawisk, tekstów itp." (s. 11). I jeszcze twierdzi: „Moim celem było (...) czytanie niektórych tekstów, wydobywające $\mathrm{z}$ nich te idee i usymbolicznione wartości, które służyć mają wyrażaniu inności wobec zewnętrza i tożsamości wobec wnętrza wspólnotowego. (...) Z tego względu podstawowymi kategoriami (w tej książce - J. Cz.) są etniczność, tożsamość, wspólnota, mniejszość, centrum, peryferie, pogranicze (dodajmy od siebie: kategorie spożytkowane i przez socjologów, i kulturologów). One będą zarówno dostarczać kluczy i pojęć interpretacyjnych, jak i stanowić niezbędną płaszczyznę wnikania w kontekst społeczny, jaki generuje, formułuje i absorbuje teksty literackie" (s. 12-13). Tak czy inaczej przy takim założeniu teksty literackie w książce nie są analizowane w swej funkcji estetycznej. Są dla szanownej Autorki jedynie materiałem egzemplifikacyjnym, ilustrującym inne twierdzenia i przesłanki. „Literaturę rozumiem jako jeden z dyskursów kulturowych - stwierdza nieco wcześniej ściśle konfrontujący się z innymi dyskursami i wytwarzający z nimi liczne płaszczyzny przenikania" (s. 7). Toteż podstawowym, zasadniczym tematem w rozprawie 
jest w całej swej socjologiczno-kulturowej złożoności kwestia mniejszości etnicznej. A w jej centrum stawia „sprawę łemkowską”, czyni ją wiodącą, aczkolwiek bazę tekstową poszerza o jeszcze dwie literatury mniejszościowe w Polsce, białoruską i ukraińską, które, jak się wolno domyślać, mają uaktualnić i uaktywnić ważkość mniejszościowych procesów i zmian „łemkowskich”, wskazać na ich współbieżność z innymi mniejszościami i na dziejową nieprzypadkowość oraz nadać im status wspólnych działań i oczekiwań.

Otóż takie zestawienie etnicznej mniejszości łemkowskiej z narodową mniejszością białoruską i ukraińską wydaje się być co najmniej sporym uproszczeniem. Dlatego że, po pierwsze, w odróżnieniu od Łemków, Białorusini i Ukraińcy polscy mają za plecami duchową praojczyznę w postaci państw narodowych. Po drugie, jedna jest literatura białoruska, podobnie jak ukraińska, polska czy rosyjska niezależnie od miejsca jej powstania. I literatura tworzona poza metropolią wcale nie zasklepia się na problematyce mniejszościowej, regionalnej, jak twierdzi się w książce. Po trzecie wreszcie, gdy chodzi o mniejszość białoruską w Polsce, nie wpisuje się ona w ,studia postkolonialne”. Od wieków bowiem Białorusini polscy są w swoim domu jako spadkobiercy Wielkiego Księstwa Litewskiego, ojczyzny Obojga Narodów. Ukształtowana przez wspólną historię mentalność białoruska nie stawia literatów mniejszości białoruskich, a także prostych ludzi w opozycji ani do władzy rzeczywistej, ani do symbolicznej, ani do jakiegokolwiek centrum. Białorusini polscy nie dążą do „uzyskania niepodległości” (s. 256), nie czują się skolonizowani, nie odczuwają, że są w pozycji podporządkowanej, zmarginalizowanej, zredukowanej, nie żyją w poniżeniu, nie są również „wyizolowani wobec dominującego dyskursu".

Z tego względu rozdział drugi książki, zatytułowany „Postkolonialne pytania i odpowiedzi", zupełnie nie przystaje do opisu literatury i sytuacji mniejszości białoruskiej. Jest on raczej świadectwem wpadnięcia Autorki w niewolę uczoności. Swoje oczytanie w zachodnioeuropejskich teoriach kolonialnych i postkolonialnych, które wyrosły w oparciu o historyczne fakty przecież dalekich od nas regionów świata, z całym dobrodziejstwem inwentarza myślowego Duć-Fajfer przeniosła na realia polskie. Niezrozumiały w naszej rzeczywistości jest postulat otwierający ten rozdział i powtórzony jeszcze w zakończeniu: „Efektem tych działań (demaskowanie przyczyn procesu kolonizowania - J. Cz.) ma być uwolnienie tekstów i umysłów podległych spod nacisku dominacyjnego” (s. 59) oraz: „(...) uwolnienie tekstu i podążającej za nim myśli od nacisku gotowych konstruktów i schematów społecznych wygenerowanych przez centra i przejętych (...) przez peryferie" (s. 94). Wydaje się również być nieadekwatne do polskiej rzeczywistości, pochopne następujące uogólnienie: „W tekstach mniejszościowych w Polsce odnaleźć można generalnie większość (...) dyskursywnych figur i strategii postkolonialnych" (s. 89). Nie ma dostatecznych i właściwych przesłanek, aby tak oto jeszcze raz generalizować: „Wydaje się, że właśnie na gruncie pojmowania roli pisarstwa w uzyskaniu niezależności, czyli własnego głosu, własnego wyrazu, własnej ekspresji, istnieją najściślejsze paralele literatur mniejszościowych z pisarstwem byłych kolonii" (s. 256).

A jednak wszystkie moje powyższe uwagi są wynikiem opcji białoruskiej nie zawsze przecież także wolnej od narodowego subiektywizmu w stosunku do tego panoramicznego obrazu, który przedstawia Autorka. Rzecz w tym, że roz- 
prawa u podstaw, podkreślmy to jeszcze raz, oparta jest o „sprawę łemkowską”. To „sprawa łemkowska” tworzy tu centralny punkt widzenia. To z pozycji łemkowskiej jest czyniony ogląd, analiza i interpretacja literatury mniejszości narodowych i w pierwszej kolejności twórczości łemkowskiej. Aby zaś „sprawa łemkowska” na tle innych mniejszości narodowych została zauważona, aby zaistniała w świadomości odbiorcy, czytelnika, słuchacza, Autorka zapewne słusznie zaostrza granice nie tylko uwarunkowań historycznych i społecznych, granice pamięci, wartości przestrzennych, tożsamości etnicznej, językowej, religijnej, lecz zaostrza także granice pojęć, terminów i kategorii, którymi się posługuje. Pisze: „Grupy, które własnego państwa nie posiadają albo znajdują się poza jego obrębem, same muszą takie granice wyznaczać" (s. 315).

Duć-Fajfer zatem nie szuka zbliżeń, podobieństw i równobieżności zjawisk i losów mniejszościowych z większością. Odwrotnie, zarysowuje ostre linie podziału. Rozsuwa przestrzeń pomiędzy bukwą a literą. Swoim głównym celem w książce stawia ukazanie opozycji tekstualnej wobec struktur centrum. Przywołuje na pomoc odległe wzorce postkolonialne. Toteż nic dziwnego, że kluczową, nadrzędną dla koncepcji całej swej książki czyni - jak stwierdza we Wstępie - kwestię Innego, obcego, odmiennego (s. 12). „Moim celem nie było - informuje - stworzenie jakiegoś przekrojowego oglądu wybranych literatur, tylko uczynienie mniejszościowego głosu słyszalnym" (s. 315).

Spojrzenie na książkę „Od bukwy od litery” z tej właśnie, łemkowskiej perspektywy nieoczekiwanie ukazuje nam ją jako bardzo uporządkowaną, przemyślaną i bogatą w szczegóły budowlę, w której jest swój ład i wewnętrzna logika poziomych i pionowych przejść pomiędzy pomieszczeniami. Każdy z sześciu pięter-rozdziałów stanowi jakby odrębne kompetentne studium ze swoimi roboczymi przesłankami, argumentacją i konkluzjami. Wszystkie jednak są sprzęgnięte tytułową myślą przewodnią.

Powtórzmy raz jeszcze, spojrzenie na tę publikację z pozycji łemkowskiej pozwala dostrzec w niej bardzo ambitne i świeże opracowanie, bazujące na mało znanym lub wcale nieznanym materiale, opracowanie, które wpisuje literatury mniejszościowe w Polsce w niezwykle szeroki dyskurs kulturowo-humanistyczny, opatrując je po raz pierwszy całym szeregiem wnikliwych refleksji teoretycznych, opracowanie, które poszerza metodologię badań literackich i siłą rzeczy łamie nie tylko moje, jak sądzę, dotychczasowe schematy, przyzwyczajenia i wyobrażenia. To książka bardzo konsekwentna w swych założeniach i przemyśleniach, prezentująca szerokie horyzonty myślowe Autorki. To prawda, jest ona na wielu płaszczyznach kontrowersyjna, wzbudza odruch jeśli nie gwałtownego protestu, to na pewno chęć do natychmiastowej polemiki. Ale to na swój sposób bezkompromisowe zaangażowanie humanistyczne, włożenie w temat własnej osobowości, bardzo indywidualne przeżywanie tematu bardzo dobrze charakteryzuje Autorkę książki „Między bukwą a literą". 